\title{
Incomplete Correspondence: An Unsent Letter to Mary Joe Frug
}

\section{Citation}

Martha Minow, Incomplete Correspondence: An Unsent Letter to Mary Joe Frug, 105 Harv. L. Rev. 1096 (1992).

\section{Permanent link}

http://nrs.harvard.edu/urn-3:HUL.InstRepos:3141862

\section{Terms of Use}

This article was downloaded from Harvard University's DASH repository, and is made available under the terms and conditions applicable to Other Posted Material, as set forth at http:// nrs.harvard.edu/urn-3:HUL.InstRepos:dash.current.terms-of-use\#LAA

\section{Share Your Story}

The Harvard community has made this article openly available.

Please share how this access benefits you. Submit a story.

\section{Accessibility}




\title{
INCOMPLETE CORRESPONDENCE: AN UNSENT LETTER TO MARY JOE FRUG ${ }^{1}$
}

\author{
Martha Minow
}

Dear Mary Joe:

I think A Postmodern Feminist Legal Manifesto is bold, original, provocative, and fabulous. Following the title of "manifesto" with your equally confident statement of worry about the title expresses perfectly the comfort with tensions that characterizes the entire piece.

I am most impressed with your effort to articulate and then live with multiplicity and tension - as urged by postmodernists ${ }^{2}-$ despite appearances of singularity or uniformity. At the same time, I am intrigued by the points at which you choose to limit the exploration of multiplicity, perhaps guided by the substantive commitments of feminism, and perhaps guided by a desire to prevent multiplicity itself from becoming routine and predictable. I will explain both parts of this reaction as I also elaborate on what I find new and important in the Commentary.

With your focus on the female body, you join other feminists in examining the allegedly most natural and immutable source of gender difference. ${ }^{3}$ By addressing the legal meanings of female bodies, you frame the social construction discussion to integrate concrete images,

* Professor of Law, Harvard University. At the suggestion of the Editors of the Harvard Law Review, I include footnote explanations about feminism, postmodernism, and the other elements of Professor Frug's Commentary.

1 This is a response to Mary Joe Frug, A Postmodern Feminist Legal Manifesto (An Unfinished Draft), I05 HARv. L. REv. I045 (1992); Mary Joe Frug was at work on that article at the time of her murder on April 4, I9gI.

${ }^{2}$ See generally David Harvey, The Condition of Postmodernity 44-65 (I990) (describing the focus on fluidity and multiplicity in postmodern trends in varied disciplines).

3 As Alison Jaggar has recounted, early feminist theorists accepted the definition of "human" provided by male theorists and tried to show how women fit that definition. See Alison JagGar, Feminist Politics and Human NATURe 2i (I983). Later feminist theorists turned to issues such as childbearing and sexuality and began to explore and celebrate the differences between men and women, particularly those based on the differences between male and female bodies and the cultural meanings developed around those differences. See id. at 22. Similarly, feminist legal advocates working in the I970s initially challenged assertions of natural differences between men and women that had been used to deny women rights enjoyed by men, see Ruth B. Ginsburg \& Barbara Flagg, Some Reflections on the Feminist Legal Thought of the 1970s, 1989 U. CHI. LEGAL F. 9, IX, but feminist legal advocates working in the Ig80s and rggos emphasized gender difference. Advocates concerned with issues of reproduction questioned whether gender-neutral notions can accommodate biological and cultural differences between men and women. See id. at I9 \& n.38 (citations omitted). A parallel focus on the female body has animated recent feminist work in the humanities, see THE FEMALE BODY IN WESTERN Culture: Contemporary Perspectives I-4 (Susan R. Suleiman ed., I986), and especially in literary and psychoanalytic theory, see JUdith Butler, Gender Trouble: Feminism and THE SUBVERSION OF IDENTITY 79-14I (I990).

I096 
lived experiences, and discoverable ideologies about women. ${ }^{4}$ In the early I 980 , we talked about how legal feminists seemed divided between those who put sexuality at the center of feminist inquiries and discussions of women's difference and those who put maternity at the center. ${ }^{5}$ By simultaneously addressing the "maternalization" and the "sexualization" of the female body, you resist that division. Then, you connect these themes with the "terrorization" of the female body and thereby build upon the recent work by feminists on battery, rape, and other sorts of actual and threatened violence against women. ${ }^{6}$ Discussing all three themes together provides a fresh and

4 Although they address differences between men and women, most feminists remain committed to exposing the cultural - that is, the humanly invented - meanings attributed to biological differences that have been used to assign women to roles subordinate to or separate from the roles assigned to men. See Anne Fausto-Sterling, Society Writes Biology/Biology Constructs Gender, 1987 DaEdalus 61, 62-69 (examining cultural understandings of gender that become building blocks in a supposedly objective account of biology); Introduction, in Feminist Theory in Practice and Process r, 4-5 (Micheline R. Malson, Jean F. O'Barr, Sarah Westphal-Wihl \& Mary Wyer eds., I989) [hereinafter FEMINIST ThEORY] (recounting the turn to "social construction" by feminists). This notion is commonly called the "social construction" of gender and reflects a broader claim about the cultural invention of categories used to label people and assign them to particular social positions as if that assignment were compelled by their nature. See Kai T. Erikson, Notes on the Sociology of Deviance, g Soc. ProBs. 307, 308 ( 1962 ) ("Deviance is not a property inherent in certain forms of behavior; it is a property conferred upon these forms by the audiences which directly or indirectly witness them."); D.L. Rosenhan, On Being Sane in Insane Places, 179 Scr. 250, 257 (1973) (reporting that, in an experiment to test attitudes about labeling, a person identified as schizophrenic could not persuade observers that he was not mentally ill). Much of this work resonates with the theories of George Herbert Mead, who emphasized the impact of observers' perspectives on their perceptions of other human beings. See George H. MEAd, Selected Writings 134-4I (Andrew J. Reck ed., 1964).

${ }^{5}$ For example, Catharine MacKinnon puts sexuality at the center, see Catharine A. MacKinnon, Sexuality, Pornography, and Method: "Pleasure Under Patriarchy," in FEMINISM and Political Theory 207, 208 (Cass R. Sunstein ed., I9g0), whereas Robin West puts maternity and mothering at the center, see Robin West, Feminism, Critical Social Theory and Law, I989 U. ChI. LeGal F. 59, 80-81; see also Robin West, Jurisprudence and Gender, 55 U. CHI. L. REV. I, 70 (Ig88) (discussing pregnancy). Of course, both perspectives share concerns with male domination that frames women's difference from men, unlike the "sameness" feminists who focus on women's similarity to men - as described in note 3 above - or those who seek to transcend the sameness/difference debate. Several legal feminists have reviewed the debate over sameness and difference arguments in the specific context of pregnancy and maternity leave policies. See, e.g., Lucinda M. Finley, Transcending Equality Theory: A Way Out of the Maternity and the Workplace Debate, 86 CoLum. L. REv. I118, I142-63 (1986); Linda J. Krieger \& Patricia N. Cooney, The Miller-Wohl Controversy: Equal Treatment, Positive Action and the Meaning of Women's Equality, 13 Golden Gate U. L. REv. 513, 514-15 (1983); Wendy W. Williams, Equality's Riddle: Pregnancy and the Equal Treatment/Special Treatment Debate, 13 N.Y.U. Rev. L. \& Soc. Change 325 (1985).

${ }^{6}$ See e.g., ANDREA DWORKIN, Violence Against Wamen: It Breaks the Heart, Also the Bones, in LETTERS FROM A WAR ZONE, at $\mathrm{I}_{72}$, $175-76$ ( $\mathrm{Ig} 88$ ) (discussing the frequency of violence against women); SUSAN EsTRICH, REAL RAPE (1987) (examining rape); SUSAN SCHECHter, Women and Male Violence: The Visions and Struggles of the Battered Wom- 
powerful analysis in your case studies of prostitution, family and work, and monogamy, heterosexuality and passivity.

I do offer the following questions and suggestions. Does it reflect too great a preoccupation with consistency to ask for a more persistent analysis of the multiple themes in each of your examples? Can you pull all three themes through the section on family and work and the section on monogamy, heterosexuality, and passivity the way you do with the prostitution discussion? That discussion so effectively illustrates how anti-prostitution rules work in concert with other rules to communicate danger to and about women's bodies, the illegality of sexuality disconnected from marriage, and the disapproval of sexual activity remote from reproduction. Your method interplays the themes to show how female bodies are unambiguously situated in space and time and yet engender multiple meanings and possibilities. But perhaps you mean to disrupt the idea that one method, or one coherently applied approach, should be used throughout your analysis. If so, why not say so, and say why?

In contrast, your final section on the anti-pornography campaigns explores a different kind of multiplicity by challenging the presumed meaning of pornography. There, the multiple constructions of female bodies is less apparent; instead, you emphasize the centrality of women's oppression through sexual subordination. ${ }^{7}$ What about terrorization and maternalization? You mention pornography's link to violence against women and its parallel to women's oppression in the workplace. This implies attention to the several strands of women's oppression. Yet for the most part, your discussion adopts the views of MacKinnon and Dworkin about the centrality of sexual subordination to women's oppression ${ }^{8}$ rather than your earlier, more multifaceted, and complex account of the sources of women's oppression. Perhaps in this final section you mean to shift the locus of deconstruction from gender to political strategy; again, if so, why not say so, and say why? Doing so would give you the chance to acknowledge this additional feature of the tension between a desire to hold some things constant and a desire to fracture and deconstruct what seems given and immutable.

This tension between the fixed or located and the multiple or diffuse recurs in two other contexts that you identify. The first context

EN'S MOVEMENT I-8 (I982) (discussing the significant achievements of the battered woman's movement).

7 See Frug, supra note $\mathrm{I}$, at 1072.

8 Catharine MacKinnon and Andrea Dworkin have each written analyses of women's subordination that identify the conventional practices of and ideas about heterosexual sexuality such as those depicted in pornography - as central to the domination of women. ANDREA Dworkin, Pornography: Men Possessing Women (i981); Catharine A. Mackinnon, FEMINISM UNMODIFIED I83-9I (1987). 
concerns "womanhood" - is there something unifying women or are women in our plurality too different to be united on the basis of gender? You imply a powerful parallel between "the body" and "womanhood," which both are palpable and yet also multiple and mutable. You warn against seemingly "natural" meanings of sex or gender that imply unity because the very attribution of "natural" meanings hides their invention by humans and produces political immobilization. ${ }^{9}$ But, as you acknowledge, deconstructive techniques that emphasize the multiple meanings of gender and womanhood also threaten a different kind of political paralysis: the classic technique of "divide and conquer" splinters the group that is trying to challenge common oppression. Granted, in the late twentieth century we cannot speak as nineteenth-century activists did of the "Woman movement." 10 We encounter variety - and even conflicts - among women. ${ }^{11}$ But reading that variety as so profound that nothing remains common across all women makes it seem difficult - if not impossible - to speak of women as a group, women with shared interests, or women as a coherent political concept. You suggest the tension between the unifying and multiple conceptions of womanhood and women, and you embrace both. It seems "women" has too much historical and present-day meaning to be jeopardized by scholarly deconstruction; sex differences exist and cannot be transcended. ${ }^{12}$ Yet analysis of the competing strands of meaning offers a sense of possibility and room for resisting imposed meanings. Actual political work building upon women's lived experiences, you suggest, can "deploy the commonalities among real women" and "at the same time challenge the conventional meanings of 'woman' that sustain the subordinating conditions of women's lives"13 I see the tension, and I am given hope by your effort to embrace both sides.

The second context you use to explore the tension between multiplicity and singularity concerns law and law reform. So much of feminist political work has sought to adopt legal tools to produce new and improved, reliable reforms of official rules in order to help women. ${ }^{14}$ Postmodern work, in contrast, explores the multiplicity of

${ }^{9}$ See Frug, supra note I, at $105 \mathrm{I}$.

10 See Nancy F. CotT, The Grounding of Modern Feminism 5 (1987) (contrasting the nineteenth-century "Woman movement" with currently diverse strands of the women's movement).

11 See Elizabeth V. Spelman, Inessential Woman: Problems of Exclusion in FemINIST THOUGHT 160-64 ( 1988 ) (arguing that the variety of women should not prevent political work on women's issues but that it should stop anyone from claiming to speak for all women without having engaged in collaborative consultation with the women on whose behalf she claims to speak).

12 See Frug, supra note I, at I051-52.

13 See id. at 1059.

14 See Ginsburg \& Flagg, supra note 3, at $\mathrm{1} 3-\mathrm{r} 8$ (discussing efforts to challenge the exclusion 
meanings within language itself. ${ }^{15}$ Brought to law, this postmodern work challenges feminist law reform by interrogating the very terms the feminists want to use, terms such as "woman." You urge readers to work with this resulting tension and not get lost in either side. Thus, law reformers should acknowledge and welcome the fluidity of language and meanings and participate in controversies about discourse rather than hoping to pin things down. Reformers such as the proponents of the anti-pornography ordinance should consider a shift from the focus on winning to a focus on opening up discussion and expanding the array of images of women. ${ }^{16}$ This message is even more pronounced for feminist reformers who opposed the anti-pornography ordinance. ${ }^{17}$ That ordinance fractured women's groups and simultaneously drew on support by conservatives who oppose other feminist goals. Welcoming multiplicity here means that feminists who are opposed to the anti-pornography campaign should lighten up and should recognize the benefits of both shifting alliances and a "broad theater of political involvement."18 At the same time, you also urge

of women from serving as bartenders, jurors, and estate administrators, and from voting, as well as the efforts to challenge the exclusion of men from programs granting spousal benefits to spouses of military officers and from child-in-care social security benefits). Challenging the exclusion of men reflected the broader strategy of securing heightened scrutiny for any genderbased distinction on the theory that such scrutiny would ultimately help women.

is See e.g., Butler, supra note 3 , at $25-34,142-49$ (examining the power of language to encode gender meanings and discussing postmodern theorists who deconstruct - take apart while highlighting - those meanings); Chris Weedon, Feminist Practice aNd PoststrucTURALIST THEORY 8I-85 ( 1987 ) (comparing feminist-humanist ideas that language can unproblematically express experience with postmodern notions that language hides multiple meanings and hidden sources of ideas and experience). See generally Jonathan Culler, ON DeconSTRUCTION 3I-42 (1982) (explaining postmodern methods of interpretation that expose, reverse, and disassemble dichotomous meanings implicit in texts); Elizabeth A. Meese, Crossing the DoubLE-CROSS 149-50 (I986) (endorsing postmodern methods for use by feminists to pursue an infinite progression that refuses to identify a center and is always self-displacing, self-contradictory, fluid, and in motion).

${ }^{16}$ See Frug, supra note $\mathrm{r}$, at 1067-68.

${ }^{17}$ A group of feminists organized to oppose the anti-pornography ordinances and produced the Brief Amicus Curiae of Feminist Anti-Censorship Taskforce, American Booksellers Ass'n v. Hudnut, $77 \times$ F.2d 303 (7th Cir. 1985), aff'd, 475 U.S. Ioor (I986), reprinted in Nan D. Hunter \& Sylvia A. Law, Brief Amici Curiae of Feminist Anti-Censorship Taskforce, et al. in American Booksellers Association v. Hudnut, 2 I U. Mich. J.L. REF. 69, 76-136 (1987-I988). Feminist opponents of the anti-pornography campaign have also written scholarly commentaries. See Lisa Duggan, Nan Hunter \& Carole S. Vance, False Promises: Feminist Antipomography Legislation in the U.S., in WOMEN AGAINST CENSORSHIP I30, 145 (Varda Burstyn ed., 1985) (arguing that pornography is not harmful enough to justify restrictions on speech). For many feminists, the anti-pornography campaign would undermine feminist efforts to explore and experiment with sexuality. See Carole S. Vance, Pleasure and Danger: Toward a Politics of Sexuality, in Pleasure and Danger: Exploring Female Sexuality 1, 6-7 (Carole S. Vance ed., 1984) (describing support among feminists for sexual autonomy).

${ }^{18}$ Frug, supra note $\mathrm{I}$, at I070. Welcoming this challenge to the conventional political groupings produced by the anti-pornography campaigns is related to - but still differs from - 
postmodernists to resist the temptation to abandon practical law reform struggles as fruitless because of the multiplicity of meanings, and you encourage them instead to join the constructive impulse of the reformers. Postmodernists can join reformers in their political struggles and still celebrate the gaps and conflicts among possible meanings of sexual identities and differences.

It is quite a tour de force to turn the fight between these two groups into a source of possibility and hope. As you know, many reformer-types feel threatened by what they experience as corrosive and nihilist postmodern critiques; many postmodernists seem to disparage law reformers as naive and as engaged in a fruitless and misguided effort to freeze meanings. ${ }^{19}$ In your opening statement of the first "principle," your discussion of the sex workers' proposals to reform prostitution laws, and your analysis of the anti-pornography campaigns, you coax both groups to learn from one another. This takes the best of postmodernism and the best of feminism without trashing either one.

I have two questions that mean to explore what is deliberate and what is not deliberate when you both extend and stop your pursuit of multiplicity. I think you may carry that pursuit too far in one

an endorsement of the consciousness-raising aspects of the anti-pornography campaign. See Martha Minow, Adjudicating Differences: Conficts Among Feminist Lawyers, in CoNFLICTs IN FEMINISM 149, 160 (Marianne Hirsch \& Evelyn F. Keller eds., 1990). I wonder if someone who welcomes disruption of usual political alliances would also welcome a challenge to a single, if complex, view of women's oppression. See Frug, supra note I, at 1049-50.

${ }^{19}$ This is my experience with study groups discussing these issues. Some of this tension appears in print. As one who sympathizes with reformers, I have written:

Unlike the postmodernists, whose politics often remain hidden or diffuse, the scholars from the margin [who advocate rights for women and people of color] feel the urgency of political action and the need for aspiration, direction, and change . . . . [P]ostmodernists may respond, with some force, that $I$ have fallen into the old trap of consoling myths of reason, and have made the particular mistake of treating identities and experiences as essential and grounded rather than shifting and containing their opposites .... [But any] theory that seems to produce quiescence and a sense of helplessness is not good enough.

Martha Minow, Partial Justice: Law and Minorities, in The FATE of LAW 15, 62-63 (Austin Sarat \& Thomas R. Kearns eds., I99I). In contrast, a postmodernist has written:

What I am now going to write can easily be misread as "postmodern modesties replac[ing] Marxist certitudes," as anti-libertarian anti-feminist irresponsible talk. This is the risk that one must run in order to understand how much more complicated it is to realize the responsibility of playing with or working with fire than to pretend that what gives light and warmth does not also destroy.

Gayatri C. Spivak, Constitutions and Culture Studies, 2 YALE J.L. \& HumaN. 333, 145-46 (Iggo) (quoting Jeffrey C. Goldfarb, The Age of Dissent: Democracy Crashes Party, VillaGe VorCE, Oct. I 989 (Literary Supplement No. 79), at I8. A similar argurnent appeared when scholars of color challenged the critique of rights advanced by members of the conference on critical legal studies. Critical legal studies scholars had charged rights discourse as mind-numbing and misguided translations of complex human hopes; scholars of color responded by defending rights as empowering and unlikely to delude oppressed people. See Symposium, Minority Critiques of the Critical Legal Studies Movement, 22 HARV. C.R.-C.L. L. REV. 297 (1987). 
instance and stop short, appropriately, in another, but I think both deserve self-conscious discussion.

First, let us look at your pursuit of multiplicity in the context of pornography. In general, you endorse the anti-pornography campaigns, although you are not displeased with their ultimate failures. Yet could those campaigns take place at all if their leaders questioned their understanding of pornography and pluralized the responses readers have to pornography? Your discussion of the anti-pornography campaigns, along with your discussions of prostitution, work and family, and monogamy, heterosexuality, and passivity, challenge "the natural" by showing the fractures and contrasts among images of women and femaleness. But your anti-pornography discussion does so not by unwinding the themes of terrorization, maternalization, and sexualization, nor by exploring the competing and yet still womeninitiated perspectives on the problem (as the prostitution section does). The anti-pornography section challenges the conflation of particular bodily experiences with subjective imagination and the merging of sex with gender by introducing the arresting thought that pornography works - it appeals and seduces, entices and excites - in part by cross-sex and cross-gender identification, by men identifying with women and vice versa. As your argument makes explicit, this idea explodes the claims about sexual subordination advanced by the antipornography campaigners. For if women can and do identify with men who sexually subordinate them, and if men can and do identify with women whom men subordinate, then imagination transcends the links between sexual subordination and gender oppression.

Now, one could object that the gender hierarchy is still perpetuated through such identification. ${ }^{20}$ Indeed, the ordinance explicitly states that sexual subordination, not subordination of a biologically female person, is the critical defect of condemnable pornography. Depictions of men in sexually subordinated positions would fall within the ordi-

\footnotetext{
20 One response is that such domination and subordination is inevitable, an idea that $A$ Postmodem Feminist Legal Manifesto attributes earlier to post-Freudian, Lacanian theories of the self. See Frug, supra note I, at ro70. Therefore, it is a mistake to challenge depictions of what are inevitable constructions of self within hierarchial relationships. See id. Unlike Freud, who tied his theories of human psychology to biological drives, Jacques Lacan shifted the psychological inquiry to the allocation of meaning and being through language structured within a patriarchal society. See Jacques Lacan, The Meaning of the Phallus, in Feminine Sexuality: JacQues LaCAN AND THE Ecole Freudienne 74, 78-83 (Juliet Mitchell \& Jacqueline Rose eds., Jacqueline Rose trans., 1983); see also BUTLER, supra note 3, at 43-57 (discussing Lacan). But not everyone agrees with Lacan. Indeed, acknowledging and embracing the contemporary fights about theories of the self means leaving open the possibility that Lacan's theory is wrong. See Frug, supra note I, at Io7o. And if that theory is wrong, pornography may well contribute importantly to the perpetuation of subordinating relationships. So keeping an open mind on the question of "the self" means keeping an open mind on the significance of pornography.
} 
nance's terms. ${ }^{21}$ Other than undermining the rhetorical and conceptual coherence of the anti-pornography campaigns, then, what does this notion of cross-gender identification offer? The deeper goal, you suggest, is to challenge "the polarization of the world by gender."22 Exploring each of our capacities to identify with people of different genders could help. But my question is whether exploring such capacities in this context would undermine the very notion of gender subordination that the anti-pornography campaign, and feminists more generally, challenge. ${ }^{23}$ If we can each imagine ourselves on various sides of subordinating relationships, what is so bad about subordination? If we can each pretend to take turns with power, or transcend our positions through imagination, why is oppression deserving of critique?

My second question is related. The manifesto displays a commitment to deconstruct - to take apart apparent dichotomies and show how apparent polarities need or compliment one another or exclude other important alternatives. I have already commented on a seeming shift in the focus for deconstruction. In the first three cases it is gender, whereas in the anti-pornography discussion, the focus is the definition of and readers' responses to pornography. My question here is why do you not deconstruct the notion of subordination itself? I think I have an answer; I think that your commitment to deconstruction is not for its own sake or to produce a mindlessly perpetual analytic machine that fractures concepts and ideas. I think that you are a feminist using techniques of postmodernism, just as you are a feminist using law. 24 Yours is a "postmodern feminist manifesto," not

${ }^{21}$ See The Minneapolis Civil Rights Ordinance, With Proposed Feminist Pornography Amendments, 2 CoNST. CoMmeNTARY I8I, I84 (1985) (reprinting proposed amendments to Minneapolis, Minn., Code of Ordinances, tit. 7, chs. 139 \& I4I) ("The use of men, children, or transsexuals in the place of women . . . is pornography for purposes of . . this statute."); see also INDIANapolis \& Marion CoUnTy, IND., CODE $\$ \S$ I6-I, $-17,-18,-24,-26$ to -28 (1984), reprinted in Symposium on Pornography 20 NEw ENG. L. REv. 767-72 app. (1984-1985).

${ }^{22}$ Frug, supra note $\mathrm{I}$, at 1075 .

23 The anti-pornography campaign as framed by its feminist supporters was premised on the idea that the subordination and oppression of women operates through male dominance that is itself sexual. MacKinnon argues specifically that rape, battery, sexual harassment, and prostitution, along with pornography, are manifestations and confirmations of the forms of power men hold over women. MacKinnon, supra note 5, at 208. Even those feminists who do not agree with this particular theory or with the focus on pornography challenge the persistent power that at least some men are able to wield in ways that hurt most women. My question concerns whether exploring the capacities of each person to identify with persons of different sexes undermines such analyses of and struggles against male subordination of women.

24 There are parallel dangers for feminists in being drawn into these other enterprises postmodernism or law - and falling into their rhythms and assumptions rather than pursuing our own. Compare Jean B. Elshtain, Antigone's Daughters, in Freedom, Feminism, and THE STATE 6I, 6I (Wendy McElroy ed., 2d ed. I99I) (exploring the dangers of feminist reliance on 
a feminist postmodern manifesto. You want to be in control of your postmodernism just as Madonna wants to assert her control over her dress, her images, her fantasies, and her life. ${ }^{25}$

But why don't you talk about just this: how you mean to be in charge as you use postmodernism? Why not articulate more fully what you mean by oppression and subordination? Might that expose the analysis to the deconstructive impulses of some readers? What happens in the absence of direct discussion? Do you adopt Barbara Johnson's notion that examining ambiguities always enables liberating challenge to the established order? ${ }^{26}$ Or do you find helpful Sandra Harding's idea that postmodernism risks a relativism that conflicts with feminist commitments to political engagement, and with a continuing ability to name, authoritatively, and to fight, effectively, what is oppressive?27 Or is any talk about how we know that oppression is bad and what it is in fact just beside the point? Does such talk risk falling into verbal games that we know only too well, the games that give "academic" a bad name?28 Are irony and playfulness your ways of remaining in control and guarding against the Pac-Man tendency of postmodern methods, or are they signs that you have already been attacked and absorbed by those methods?

Actually, I think your irony, playfulness, and eminently personal style $^{29}$ bring delight and reassurance that your self is there, intact, in control, and enjoying engagement with the reader. Your "popover"type comments ${ }^{30}$ are disruptive in the best sense: they resist the lull of seamlessness in the prose and the illusion of authorlessness. Your confessions and self-reflections are like the refining lines on an etching that make the figure more palpable while complicating its actual boundaries. I get a charge thinking about "premenstrual" and "postmenopausal" and certain four-letter words appearing in a law review. I love the fact that the "spell-check" on my computer software does not recognize many of your words. These aspects of your style ex-

the state) with Linda Alcoff, Cultural Feminism Versus Post-Structuralism: The Identity Crisis in Feminist Theory, in FEMINIST THEORY, supra note 4, at 295, 295-326 (exploring poststructuralist challenges to feminists).

${ }^{25}$ See Frug, supra note I, at 1053.

${ }^{26}$ See Barbara Johnson, A World OF DIFFerence 30-3I (I987).

${ }^{27}$ See Sandra Harding, The Instability of the Analytical Categories of Feminist Theory, in FEMINIST THEORX, supra note 4 , at $15,26-27$.

${ }^{28}$ Cf. Arthur A. Leff, Unspeakable Ethics, Unnatural Law, 1979 DukE L.J. 1229, 1249 (responding to the intellectual notion that "everything is up for grabs").

${ }^{29}$ Mary Joe Frug discusses attention to style and worries about meeting the postmodern demands for self-consciousness about style. See Frug, supra note I, at 1047-48. Her talents for inventing a personal style characterized her dress, her speech, her teaching, and her friendships, as well as her scholarship.

30 Mary Joe writes: "Like a shooting star or last night's popovers, [the] genius [of postmodernism] was the surprise of its appearance." Id. at I045. 
emplify the idea of opening things up that your analysis pursues, just as your own dress and direct questions to people do.

I get more out of the text with each rereading. The last time I read it I noticed some zingy phrases, such as "Vanilla-Sex Gestapo"31 and "Madonna's bambino puts her in charge" 32 (which echoes ironically Madonna's assertion that "I'm in charge"). ${ }^{33}$ Re-reading gives me the chance to be a different reader each time, and to imagine how a feminist critical of using law and a male reader with a chip on his shoulder could perceive the arguments. ${ }^{34}$ Perhaps a feminist critical of law reform would find the piece a teasing way to entice reformers into postmodernism. Perhaps a male reader with a chip on his shoulder would be looking for clues to justify his anger, and he would find them in your insistent refusal to be pinned down and to abide by law review conventions.

Re-reading also prompts further questions. Why do you find Madonna believable when she says she is in control? Is wearing a leather skirt resistance to the fear of looking like a whore or a parody of prostitute attire? Did you use the word "terrifying" deliberately when you write: "[T]he polarization of the feminist legal community during the ordinance campaign was terrifying to me"?35 Your very next sentence remarkably pulls resistance to terror from your own confident hope in challenge, difference, and change: "However, I believe the divisions the campaign produced among feminists constituted an important challenge to the polarization of the world by gender."36 It is your confidence, I confess, that moves me even more than your analysis, your hope even more than your deconstructions. And I hope to emulate that confidence as I face what is terrifying in this world.

As always,

Martha

31 Id. at 1070 .

32 Id. at 1056 .

33 Id. at 1053 (quoting Madonna).

${ }^{34}$ Cf. Mary Joe Frug, Re-Reading Contracts: A Feminist Analysis of a Contracts Casebook, 34 AM. U. L. REv. 1065, 1065 (1985) (contending that 'readers' views about gender affect their understanding of a law casebook").

${ }^{35}$ Frug, supra note $\mathrm{I}$, at 1074 .

36 Id. at 1075 . 